\title{
Brazilian growth in the mainstream science: The role of human resources and national journals
}

\author{
Jacqueline Leta \\ Instituto de Bioquímica Médica, Universidade Federal do Rio de Janeiro, BRAZIL
}

\begin{abstract}
In the last decade, the number of Brazilian publications in the main international databases has increased considerably. Using data from Scopus and Web of Science, the present study aims at discussing the recent trends of Brazilian science in the contexts of the training and qualification of personnel to the sector and the role of national journals. Both seem to be key factors in a scenery where Brazilian science gained more space in international databases but not international audience.
\end{abstract}

Keywords: Scientometrics, S\&T indicators, human resources.

\section{INTRODUCTION}

Studies on Brazilian science, using scientometrics indicators, began in the late 1970s (Morel \& Morel, 1977). In the following decades, there were some initiatives from institutions from the public sector to disseminate statistics and indicators of S\&T performance, human resources training and expenditures. Recent efforts towards mapping Brazilian science came especially from the Ministry of Science and Technology (Brazil, 2001, Brazil, 2002), the Science Foundation of the State of São Paulo (FAPESP, 2002; FAPESP, 2005), the Brazilian Academy of Science (ABC, 2002) and also from international bodies such as UNESCO (UNESCO, 2010).

From academia, Brazilian science has been portrayed within the international and national context and through different perspectives. In 2009, for instance, Ingwersen (2009) drew comparisons between Brazilian performance of science with Mexico and South Africa. The author points out that, unlike these two countries, Brazil has become more global in terms of topics and journals. Other publications devoted to investigate Brazilian science, within a scientometric view, have also been published. The majority focuses on the country's scientific

${ }^{\star}$ Corresponding author.

E-mail: jleta@bioqmed.ufrj.br

DOI: 10.5530/jscires.2012.1.9 production as a whole or in a particular field or institution (some examples: Leta \& de Meis, 1996; Meneghini, 1996; Sikka, 1997; Chaimovich, 2000; Pinheiro-Machado \& Oliveira, 2001; Zanotto, 2002; Glanzel et al, 2006; Brito Cruz, 2007; de Meis et al, 2007). One of the most frequent findings of these studies is the increase in the share of Brazilian publications in the international scene.

Recently one of the most prestigious scientific journals, Science, has exalted Brazilian performance within the world mainstream science. The paper, entitled Brazilian Science: Riding a Gusher, calls attention to the positive effects of the current expansion of economy and oil discoveries on Brazilian science (REGALADO, 2010). Among the indicators presented in this paper, the author highlights the number of publications in journals catalogued by the Thomson Reuters database, Web of Science (WoS). Accordingly, the number of Brazilian publications in WoS increased from 6,038 in 1997 to 32,100 in 2007, an increase that was also observed in the share of Brazilian publications to the total of this database: from $0.8 \%$ to $2.7 \%$ in the same period. This performance has led Brazil to jump to the $13^{\text {th }}$ position in the world ranking of scientific publications.

The larger participation of Brazil in worldwide science was celebrated by different sectors and diffused widely in both local and international media (some examples: King, 2009; Folha de São Paulo, 2009; BBC/Brazil). However, in most cases, this discussion fails when it comes to pointing out 
some possible factors involved with such success. Hence, considering the current picture of Brazilian science, this paper aims at presenting the country's performance at two important scientific databases, Scopus and Web of Science during recent years and its relationship to both the training of human resources to the sector and the enlargement of Brazilian journals indexed in these databases.

\section{METHODOLOGY}

This is a descriptive study based on documental analysis. The main sources are two international databases, Scopus and Web of Science (WoS) and the Brazilian Ministry of Science and Technology.

Data on Brazilian publications was collected from Scopus and WoS through their online version available for Brazilian research institutes and universities supported by federal funding. The Scopus' online database encompasses not only records with references that go back to 1996 (around 26 million) but also records published before 1996 which go back as far as 1823 (around 21 million) published in more than 18,000 titles (SCOPUS, 2012). The WoS' online database encompasses a lower number of titles than Scopus but a larger coverage in terms of register with references (WoS, 2012).

By combining two filters, year of publication (that varied from 1991 to 2010) and address (Brazil or Brasil), data was collected on May $4^{\text {th }}$ and compiled manually in an excel archive.

Data on human resources and S\&T personnel was collected directly from the website of the Brazilian Ministry of Science and Technology and the Research Group Directory, one of the units of the Ministry.

\section{BRAZILIAN SCIENCE: GAINING INTERNATIONAL VISIBILITY IN THE LAST DECADES}

Figure 1 presents the time trends of Brazilian publications indexed in two international databases, Scopus and WoS, from 1991 to 2010. In this period, Brazilian publications have increased from 3,738 to 47,292 in Scopus (12.7 fold) and from 4,523 to 40,726 in WoS (9 fold). Looking at the total number of publications catalogued in Scopus and WoS databases we found the following for the same period: from 814,914 to $2,214,410$ (2.7 fold) and from 1,044,964 to 1,895,379 (1.8 fold), respectively.

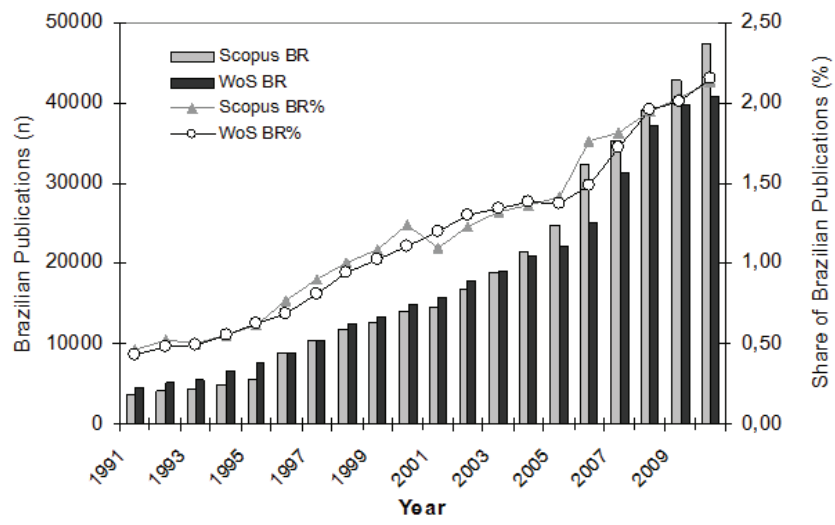

Figure 1. Brazilian publications catalogued in Scopus and WoS databases, 1991-2000.

Columns represent the number of Brazilian publication in Scopus (gray) and WoS (black). Lines represent the share of Brazilian publications in the total of Scopus (triangle) and WoS (circle) within the respective year.

Such a striking growth has enlarged the share of Brazilian publications in the period's total publications: from $0.46 \%$ to $2.14 \%$ in Scopus and from $0.43 \%$ to $2.15 \%$ in WoS.

Such continuous growth is indeed a result of many input factors which enabled the development and consolidation of the Brazilian S\&T system. This process started in the 1950s, when the most important scientific and technological funding institutions were established in the country. In the 1970s and 1980s, public policies focused on the expansion of graduate courses, that is, the training of personnel to scientific activities. At the beginning of the 1990s, funding agencies started to award fellowships to undergraduate students to stimulate their involvement with research. In the new millennium, policies for S\&T turned the focus to the design and implementation of a new financing model, the sectorial funding, as a key strategy to reduce resource instability to the sector (Schwartzman, 1991; Pereira, 2007).

At present, there is no doubt that Brazil has built up a solid S\&T system. However, one aspect to be considered is the close relationship between the Brazilian S\&T system and graduate courses mostly affiliated to universities and research institutes supported by the public sector. The funding in the training of skilled personnel, which started in 1980s, has been an ongoing process since then, resulting in a strong growth in the number of enrollments and degrees in both Masters and $\mathrm{PhD}$ courses across the country (Figure 2).

The number of students enrolled in Masters and $\mathrm{PhD}$ courses increased 2.7 (from 37,205 to 98,607) and 5.4 fold 


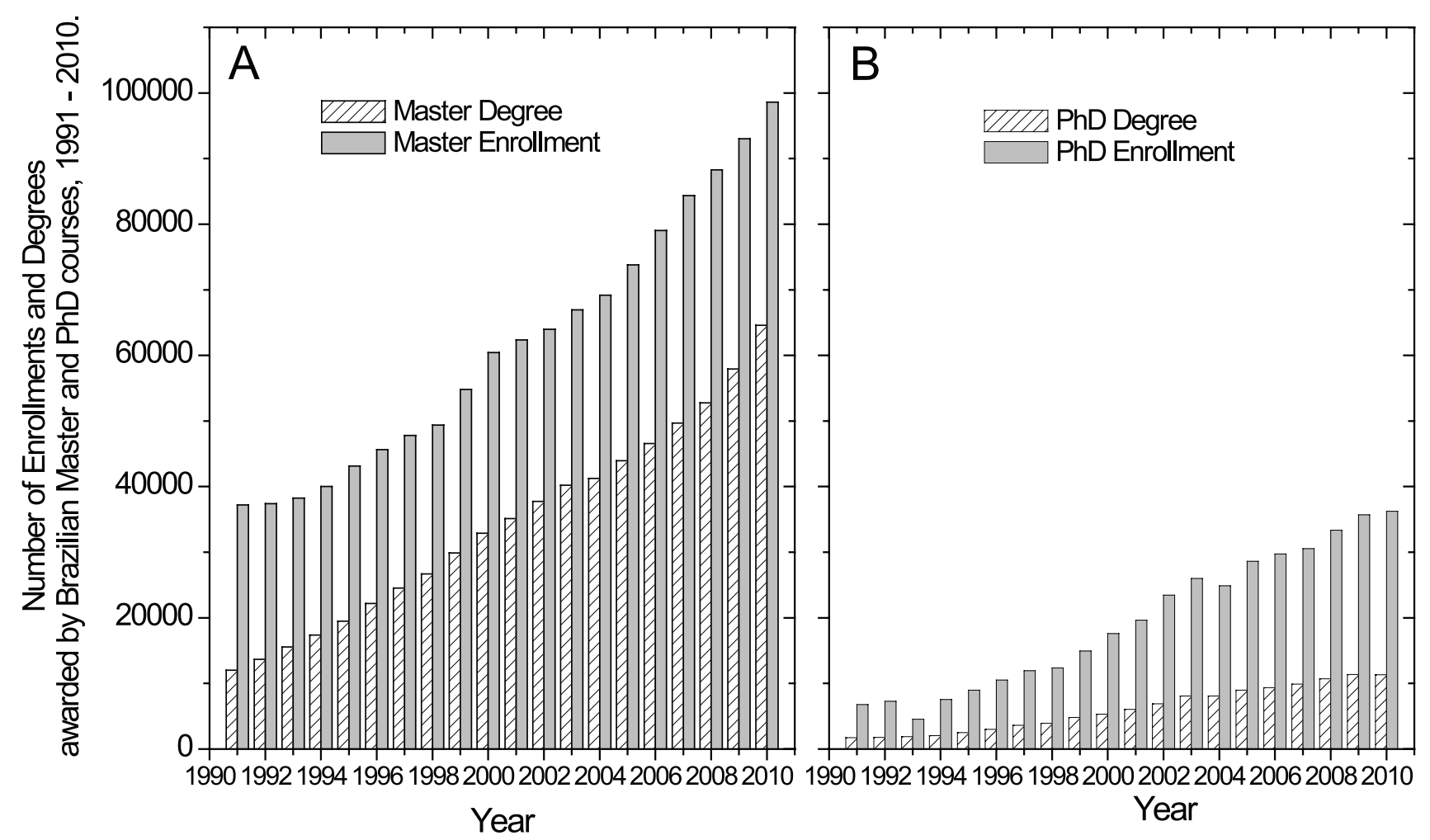

Figure 2. Number of enrollments and degrees awarded by Brazilian Master (A) and PhD (B) courses, 1991-2010. Data of Figures $2 \mathrm{~A}$ and $2 \mathrm{~B}$ is in the same scale.

Source: MCT, 2012a.

(from 12,015 to 64,588), respectively, in the period from 1991-2010. For degrees, it increases from 6,772 to 36,247 (5.4 fold) and from 1,750 to 11,314 (6.5 fold), respectively. The better performance of master students can be observed comparing both figures. Proportionally, master students tend to be more efficient in terms of getting their degrees in the expected time, 2 years, while $\mathrm{PhD}$ students seem to take more time to get their degree than expected, 4 years.

Despite these differences, Figure 2 calls our attention to the huge number of fresh masters and $\mathrm{PhDs}$ who are able to be incorporated by the Brazilian S\&T system, mainly by universities supported by federal and state fundings as shown in Figure 3). Nevertheless, as students or as novice scientists, Masters and $\mathrm{PhDs}$ are associated with Brazilian graduate courses, which are evaluated every 3 years by CAPES, a Brazilian agency for science training linked to the Ministry of Education. For decades, CAPES has been carrying out an intensive and continuous process of evaluation on all Brazilian graduate courses. This process is inclined to prioritize some international standards of productivity, pushing Brazilian students and researchers to publish in journals with high impact factor and international visibility. Hence, the higher the number of
Brazilian science personnel, the higher are the chances to publish overseas increasing the country's productivity. Taking this belief into consideration, one should agree that the first may explain, at least partially, the second effect.

\section{BRAZILIAN SCIENCE AND THE MAIN INSTITUTIONS}

The analysis of three different moments (1991, 2001 and 2010) reveals that Brazilian scientific publications mainly originated by universities are supported by public funding when the 10 most productive Brazilian institutions are considered (Table 1).

Along the three studied years, USP has remained number one in rank among the most productive institutions while UFRJ, UNICAMP and UNESP have alternated the number two in this ranking. As a representative of non universities, we found Fiocruz, a research institute linked to the Ministry of Health, whereas PUC-RJ appears as a representative of the university but supported by private funding. Both institutions, however, appeared only in the first analyzed year, 1991. 


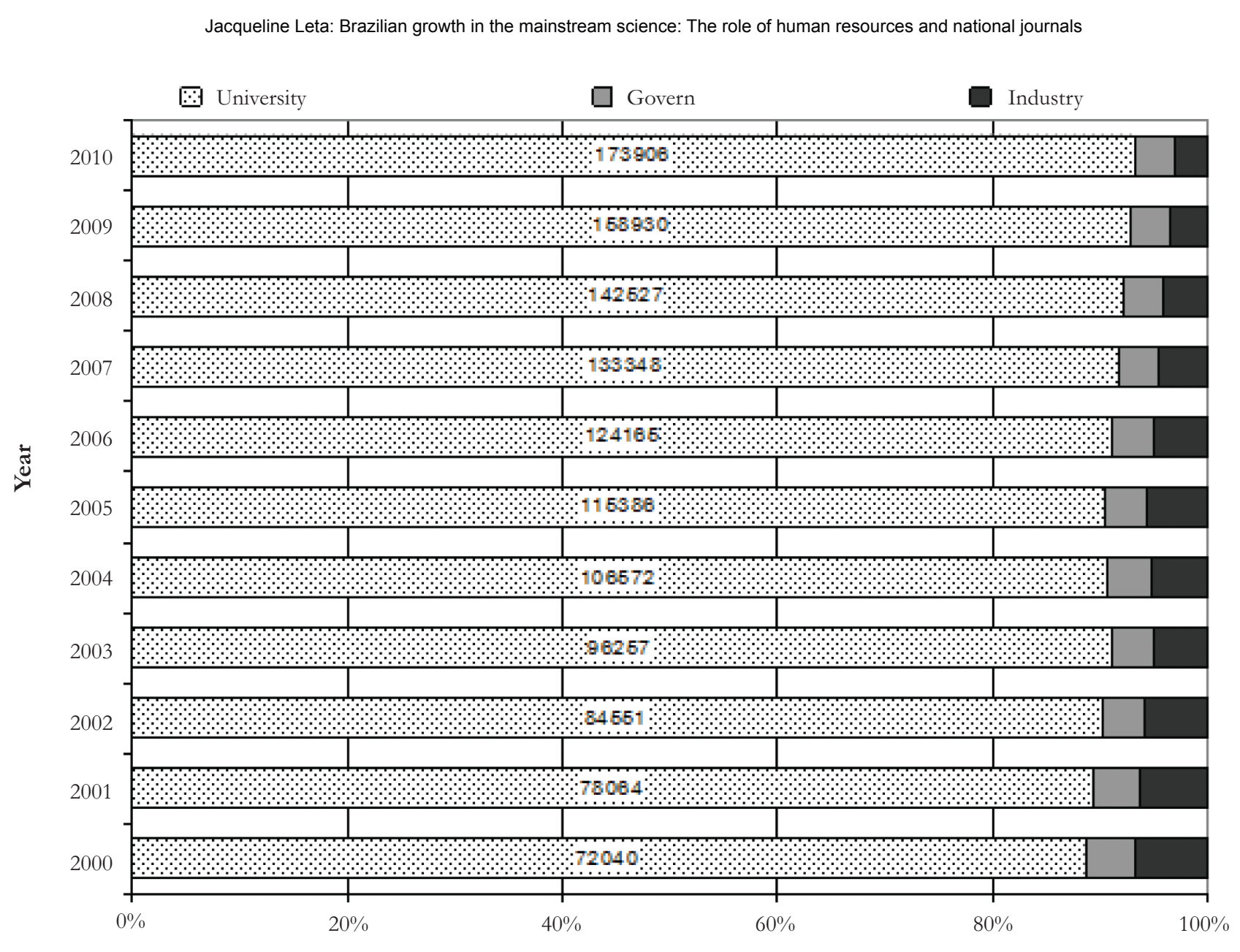

Brazilian researchers by sector, $\%$.

Figure 3. Brazilian researchers with a Masters or PhD degree by sector, 2000-2010, \%.

Source: MCT, 2010b.

Table 1. Ten most productive institutions in Brazil

\begin{tabular}{|c|c|c|c|c|c|c|}
\hline \multirow[b]{2}{*}{ Ranking } & \multicolumn{2}{|c|}{1991} & \multicolumn{2}{|c|}{2001} & \multicolumn{2}{|c|}{2010} \\
\hline & Scopus & WoS & Scopus & WoS & Scopus & WoS \\
\hline 1 & USP & USP & USP & USP & USP & USP \\
\hline 2 & UFRJ & UFRJ & UNICAMP & UNICAMP & UNESP & UNICAMP \\
\hline 3 & UNICAMP & UNICAMP & UFRJ & UFRJ & UNICAMP & UNESP \\
\hline 4 & UNESP & UNIFESP & UNESP & UFRGS & UFRJ & UFRJ \\
\hline 5 & UFMG & UFMG & UFRGS & UNESP & UFRGS & UFRGS \\
\hline 6 & UNESP & UFRGS & UFMG & UFMG & UFMG & UFMG \\
\hline 7 & UFRGS & UFPE & UNIFESP & UNIFESP & UNIFESP & UNIFESP \\
\hline 8 & Fiocruz & UFF & UFSCar & UFSCar & UFSC & UFSC \\
\hline 9 & UFPE & UnB & Fiocruz & UFSC & Fiocruz & UFV \\
\hline 10 & PUC - RJ & PUC - RJ & UFSC & UFPE & UFPR & UFPR \\
\hline
\end{tabular}

Legend: Fiocruz $=$ Fundação Oswaldo Cruz; PUC RJ = Pontifícia Universidade Católica UFF = Universidade Federal Fluminense; UFMG = Universidade Federal de Minas Gerais; UFPR = Universidade Federal do Paraná; UFPE = Universidade Federal de Pernambuco; UFGRS = Universidade Federal do Rio Grande do Sul; UFRJ = Universidade Federal do Rio de Janeiro; UFSC = Universidade Federal de Santa Catarina; UFSCar = Universidade Federal de São Carlos; UFV = Universidade Federal de Viçosa; UnB = Universidade de Brasilia; UNESP = Universidade Estadual Paulista; UNICAMP = Universidade de Campinas; UNIFESP = Universidade Federal do Estado de São Paulo; USP = Universidade de São Paulo

Among this set of institutions we also find that they are mostly located in the South and Southern regions of the country. UnB and UFPE are the two exceptions (they are located in the Midwest and Northeast, respectively) but they appear in the ranking of the most productive institutions only in 1991. Another remark is that the difference (in terms of number of publications) between the number one and number ten in ranking may reach 8 fold in Scopus and 10 fold in WoS, a strong indication that Brazilian science is highly concentrated in a few number of institutions. 
The notable performance in terms of scientific publications in international databases of Brazilian universities and research institutes linked to governmental spheres contrasts with the still low participation of the private sector. The absence of the private sector among the Brazilian main producers of scientific knowledge can be explained by the low number of Masters and PhDs that are absorbed by the industries settled in the country. Figure 3 presents the proportion of researchers with a Masters or $\mathrm{PhD}$ degree employed in Brazil by the main sectors.

This picture leaves no doubt that universities are still the largest employers of Masters and PhDs in Brazil. It is important to highlight that universities support by federal and state governs are by far the ones to employed the largest number of Brazilian Masters and PhDs. Once they start their career as university teachers, they will have a goal to be associated with a graduate course, a key aspect to be accepted and get respect and visibility by/within the Brazilian scientific community. They will be pushed to publish, especially abroad, and so they will keep not the universities but the graduate courses as the main producers of scientific knowledge of the country.

Such discrepancies among sectors and regions are strong indicatives that Brazilian science is highly concentrated in a few institutions, corroborating some previous studies (for instance: LETA et al, 2006). Considering Brazilian as a huge territory and all its regional diversity, a better distribution of science capabilities is welcome. In this sense, some national politics are ongoing but an actual change in this current scene will take still some years or decades.

\section{BRAZILIAN SCIENCE AND THE MAIN FIELDS}

The first main Brazilian research institute to gain international visibility and recognition was Fiocruz, founded in 1900, in the city of Rio de Janeiro. At that time, Fiocruz was devoted to the research within health sciences and biomedicine. Other similar research institutes, especially in the state of Sao Paulo, the richest state of the country, were also active then. Nevertheless, the emergence of dozens of research institutions and hundreds of universities, especially those supported by the public sector, during the second half of $20^{\text {th }}$ century made it possible to expand Brazilian research limits to other fields of knowledge.

Today Brazilian science permeates all fields of knowledge but that does not mean they are constituted with the same proportion of researchers, institutions, degrees awarded, etc, for instance. Also it does not mean the fields have the same rhythm for productivity. Such difference among the fields is not a particular feature of Brazilian science and it has been studied worldwide. But this may explain, at least partially, the Brazilian different performances by fields.

Table 2 presents the ten most productive fields in the three selected years, which represent different decades. Note that due to some overlapping of publications, it is not possible to compare the performance between fields. Therefore, the data will not display the share of publication in each field.

Although the list in Table 2 encompasses a restricted number of fields of each year and there are differences between the two databases in terms of fields' name and coverage, it calls attention to the fact that a large fraction of Brazilian publications are found in journals classified under the main fields of biomedicine, biosciences, agriculture and physics, being the basis for the development of Brazilian science. This picture also represents a typical example of the bio-environmental model described in the $2^{\text {nd }}$ European Report on S\&T Indicators (Reist-2, 1997) and corroborates a previous study on Brazilian science (Glanzel et al, 2006).

Noteworthy is the fact that the ten most productive fields listed in Table 2 probably represent publications mostly devoted to diffuse findings on themes of international interest. Considering all Brazilian diversity in terms of fauna and flora as well as in terms of environmental issues (such as climate, geography, rivers, etc), Table 2 raises a concern about whether and how the themes of national interest are being investigated by the Brazilian research community. It seems that this is not the emphasis of Brazilian publications available for the international audience.

One input factor that may explain the better performance in Brazilian publications in fields related to biological sciences and physics is the level of qualification of their personnel. Figure 4 presents the proportion of Brazilian researchers with a $\mathrm{PhD}$ degree within the main field from 1993 to 2010. Along the whole period, exacts \& earth sciences (encompasses chemistry and physics) and biological sciences present the highest shares of qualified personnel. In 2010, almost 80\% of researchers from these fields had a $\mathrm{PhD}$. In more recent years, agriculture and engineering tend to follow this approach. On the other hand, humanities and social sciences present the lowest shares of qualified personnel. 
Table 2. Ten most productive fields in Brazil

\begin{tabular}{|c|c|c|c|}
\hline \multirow[b]{2}{*}{ Ranking } & \multicolumn{3}{|c|}{ SCOPUS } \\
\hline & 1991 & 2001 & 2010 \\
\hline 1 & Medicine $(1,463)$ & Medicine $(3,837)$ & Medicine $(14,269)$ \\
\hline 2 & Phys \& Astro (645) & Phys \& Astro $(2,557)$ & Agri \& Biol Sc $(9,113)$ \\
\hline 3 & Bio \& Mol Bio (584) & Agri \& Biol Sc $(2,121)$ & Bio \& Mol Bio $(4,939)$ \\
\hline 4 & Agri \& Biol Sc (423) & Bio \& Mol Bio $(1,856)$ & Engineering $(4,884)$ \\
\hline 5 & Engineering (392) & Engineering $(1,427)$ & Phys \& Astron $(4,630)$ \\
\hline 6 & Imm \& Micro (333) & Chemistry $(1,415)$ & Computer Sc $(3,623)$ \\
\hline 7 & Chemistry (240) & Materials Sc $(1,293)$ & Chemistry $(3,380)$ \\
\hline 8 & Earth Sc (226) & Imm \& Micro (933) & Materials Sc $(3,099)$ \\
\hline 9 & Materials Sc (215) & Mathematics (798) & Mathematics $(2,357)$ \\
\hline \multirow[t]{2}{*}{10} & Phar, Tox \& Pha (208) & Chem Eng (719) & Environ Sc $(2,205)$ \\
\hline & \multicolumn{3}{|c|}{ Web Of Science } \\
\hline 1 & Physics (720) & Physics $(2,347)$ & Agriculture $(2,861)$ \\
\hline 2 & Agriculture (326) & Engineering $(1,525)$ & Engineering $(2,771)$ \\
\hline 3 & Life Sc \& Biom (266) & Chemistry $(1,458)$ & Chemistry $(2,565)$ \\
\hline 4 & Chemistry (263) & Dent\& Oral Surg $(1,077)$ & Physics $(2,548)$ \\
\hline 5 & Tropical Med (263) & Materials Sc (964) & Neurosc\&Neuro $(1,581)$ \\
\hline 6 & Engineering (211) & Agriculture (896) & Bio \& Mol Bio $(1,473)$ \\
\hline 7 & Res \& Exp Med (209) & Bio \& Mol Bio (783) & Materials Sc $(1,465)$ \\
\hline 8 & Gen \& Heredity (206) & Computer Sc (767) & Veterinary Sc $(1,409)$ \\
\hline 9 & Bio \&Mol Bio (198) & Neurosc \& Neuro (665) & Phar \& Phamacy $(1,362)$ \\
\hline 10 & Parasitology (182) & Veterinary Sc (563) & Pub Environ $(1,341)$ \\
\hline \multicolumn{4}{|c|}{$\begin{array}{l}\text { Scopus: Agri \&Biol. Sc. = Agricultural and Biological Sciences; Bio\&Mol. Bio = Biochemistry, Genetics and Molecular Biology; Chem. Eng. = Chemical Engineering; } \\
\text { Computer Sc. = Computer Science; Earth Sc = Earth and Planetary Science; Environ. Sc. = Environmental Science; Imm\&Micro = Immunology and Microbiology; Materials } \\
\text { Sc, = Materials Science; Phar, Tox.\& Pha = Pharmacology, Toxicology and Pharmaceutics; Phys\&Astro = Physics and Astronomy. } \\
\text { WoS.:Bio\&Mol.Bio = Biochemistry Molecular, Biology; Dent.\&Oral Surg = Dentistry, Oral Surgery Medicine; Gen. \& Heredity = Genetics, Heredity; Life Sc.\& Biom = } \\
\text { Life Sciences, Biomedicine, Other Topics; Materials Sc. = Materials Science; Neurosc\&Neuro = Neurosciences, Neurology; Veterinary Sc. = Veterinary Sciences; } \\
\text { Phar.\& Phamacy = Pharmacology, Pharmacy; Pub.Environ = Public Environmental, Occupational Health; Res.Exp.Med = Research Experimental Medicine; } \\
\text { Tropical Med. = Tropical Medicine }\end{array}$} \\
\hline
\end{tabular}

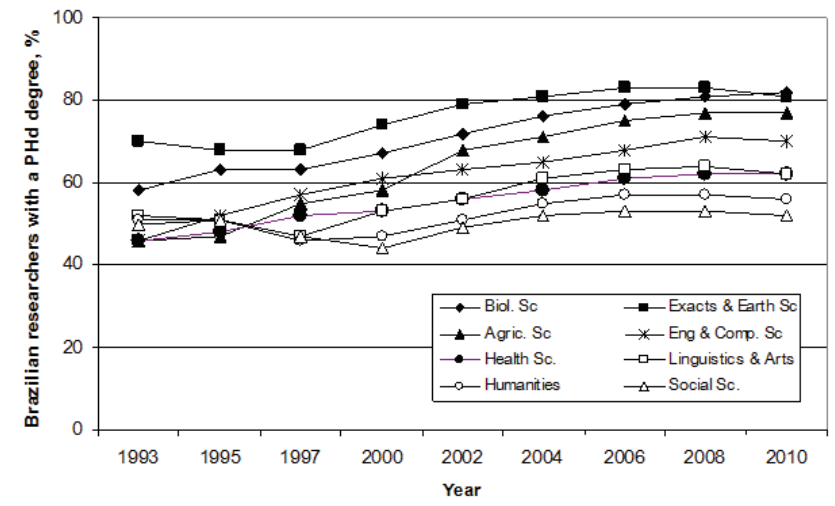

Figure 4. Share of Brazilian researchers with a $\mathrm{PhD}$ degree by field, 1993-2010.

Source: MCT, 2010c.

\section{BRAZILIAN SCIENCE: THE ROLE OF NATIONAL JOURNALS}

One of the features of modern science is the emergence of the scientific journals, which have been continuously updating and changing. After the $2^{\text {nd }}$ World War, original papers published in this media became the primary means to disseminate the new scientific knowledge (Meadows, 1974).
At present, we cannot estimate the total number of world scientific journals and original papers. However, international databases have contributed significantly to the cataloguing and dissemination part of this literature. Hence, being included in these selective collections represents a way to gain visibility either in the journal context or in the paper.

Considering Brazilian representation in Scopus and WoS, it is worth mentioning the recent increase in the number of new journals edited by the country. Web of Science, for instance, indexed 22 Brazilian journals in 2006 and 133 in 2010. Hence, more and more Brazilian journals and papers are gaining room within the mainstream science arena. Nevertheless, having more journals indexed in Scopus and WoS does not seem to represent a true gain in visibility as well. In fact, during the last decade, we witnessed a strong reduction in the proportion of Brazilian publications written in English in both databases (Table 3). This finding is accompanied by an increase in the proportion of publications written in Portuguese, as shown in a previous study (Leta, 2011).

The data collected from WoS and Scopus databases indicates that almost $1 / 5$ of the Brazilian publications published in the period from 2001-2010 is not written 
Table 3. Brazilian total publications and the share of publications written in English, 2001-2010

\begin{tabular}{cccccc} 
& \multicolumn{3}{c}{ Scopus } & & \multicolumn{2}{c}{ WoS } \\
\cline { 2 - 3 } \cline { 5 - 6 } Year & $\begin{array}{c}\text { Total Brazilian } \\
\text { publications }\end{array}$ & $\begin{array}{c}\text { Brazilian publications in } \\
\text { English, \% }\end{array}$ & & $\begin{array}{c}\text { Total Brazilian } \\
\text { publications }\end{array}$ & $\begin{array}{c}\text { Brazilian publications in } \\
\text { English, \% }\end{array}$ \\
\hline 2001 & 14,550 & 87.3 & & 15,807 & 93.6 \\
2002 & 16,840 & 86.6 & 17,827 & 93.7 \\
2003 & 18,917 & 85.7 & 19,114 & 93.3 \\
2004 & 21,591 & 86.7 & 20,966 & 93.6 \\
2005 & 24,719 & 85.3 & 22,217 & 92.3 \\
2006 & 32,432 & 78.3 & 25,057 & 92.6 \\
2007 & 35,231 & 78.2 & 31,450 & 86.4 \\
2008 & 39230 & 77.5 & 37,167 & 81.5 \\
2009 & 42,758 & 73.9 & 39,679 & 80.8 \\
2010 & 47,292 & 72.8 & 40,726 & 82.4 \\
\hline
\end{tabular}

in English. It is well known that English has become the lingua franca of science since the $2^{\text {nd }}$ World War and a key component in modern science. Hence, publishing in this language has become a universal requirement to be part of global science. However, data points out that a considerable part of Brazilian publications is not included in it since it is not published in English but in Portuguese. These findings are related to the recent entrance of many
Brazilian journals in Scopus and WoS, which are still published in our mother tongue, Portuguese.

The weight of Brazilian journals to the country's performance within the international databases can be visualized by their largest presence among a selective group composed by the 10 top journals where Brazilians have published more (Table 4). This set of journals sums 29

Table 4. Top 10 journals that have published Brazilian publications

\begin{tabular}{|c|c|c|}
\hline \multicolumn{3}{|c|}{ Scopus } \\
\hline 1991 & 2001 & 2010 \\
\hline Braz. J. Med. Biol. Res. (174) * & J. Magn. Magn. Mater. (227) & Cienc. Rural (419) \\
\hline Mem. Inst. Oswaldo Cruz (110) & Pesq. Agropec. Bras (187) & Ciênc. Saúde Colet. (357) \\
\hline An. Bras. Dermatol. (76) & Arq Neuropsiquiatr (180) & R. Bras. Zootec $(354) *$ \\
\hline Braz. J. Genet. (73) * & Braz. J. Med. Biol. Res (179) * & Quím. Nova (346) \\
\hline Arq Neuropsiquiatr (70) & Mem. Inst. Oswaldo Cruz (147) & LNCS (343) \\
\hline Rev. Inst.Med.Trop. São Paulo $(60)^{*}$ & Arq. Bras. Cardiol. (130) & Arq. Bras. Cardiol. (335) \\
\hline Phys. Rev.B(59) & Quím. Nova (125) & Mat. Sc. Forum (252) \\
\hline Rev. Saúde Públ. (57) & Cad. Saúde Pública (125) & Cad. Saúde Pública (232) \\
\hline Rev. Bras. Med. (38) & Rev. Bras.Otorrinolaringol (114) & J. Braz. Chem. Soc. $(227)^{*}$ \\
\hline Phys.Rev. D (33) & Phys. Rev. B (110) & Zootaxa (207) \\
\hline$($ sum $=750)$ & $($ sum $=1,524)$ & $($ sum $=3,072)$ \\
\hline \multicolumn{3}{|c|}{ Web of Science } \\
\hline Pesq. Agropec. Brás (248) & J. Dental Res. (882) & Cienc. Rural (430) \\
\hline Braz. J. Med. Biol. Res (176) * & R. Bras. Zootec. (279) * & Histopathol. (405) \\
\hline Mem. Inst. Oswaldo Cruz (141) & J. Magn. Magn. Mater. (229) & Ciênc. Saúde Colet. (365) \\
\hline Hypertension (88) & Arq Neuropsiquiatr (196) & Quím. nova (356) \\
\hline Braz. J. Genet. (79) * & Pesq. Agropec. Bras. (187) & R. Bras. Zootec. (335) \\
\hline Phys. Rev. B (71) & Braz. J. Med. Biol. Res (183) * & Arq. Bras. Cardiol. (262) \\
\hline Rev. Saúde Públ (67) & Mem. Inst. Oswaldo Cruz (146) & Mat. Sc. Forum (259) \\
\hline Rev.Inst.Med.Trop.São Paulo $(67)^{*}$ & Phys. Rev. B (135) & Cad. Saúde Pública (251) \\
\hline Rev. Bras. Med. (63) & Quím. Nova (133) & J. Braz. Chem. Soc. $(227)^{*}$ \\
\hline Rev. Microbiol. (63) & Arq.Bras.Med.Vet.Zootec. (123) & J. Dairy Sci. (213) \\
\hline$($ sum $=1,063)$ & $(\mathrm{sum}=2,493)$ & $($ sum $=3,103)$ \\
\hline \multicolumn{3}{|c|}{ 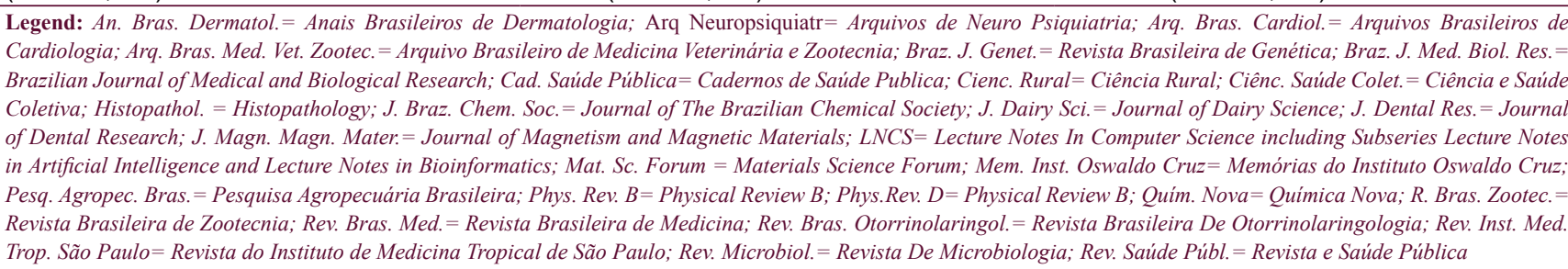 } \\
\hline
\end{tabular}


in the three studied years but only ten are not edited in Brazil (titles in bold). Among the 19 journals edited in Brazil, only four accept contributions exclusively written in English (titles with*). These journals are devoted to disseminate issues of international interest.

It is widely discussed that the field of research is a key factor to the publication profile. Hence, the low proportion of Brazilian studies in English in the selective set of journals presented in Table 4 can be related to some field's particularities. In recent works, our group has showed that the more experimental and/or technological the field, the larger is the fraction of researchers with highly international profiles. Studying the productivity of the Brazilian community, we have observed that researchers associated with more experimental fields (namely earth and exact sciences, biology and engineering) tend to publish more in international journals and in English than their colleagues from social sciences, health science and agriculture (Leite et al, 2011). We have also demonstrated that in Brazil these fields encompass the highest fraction of researchers who claim to have good skills in English writing (Vasconcelos et al, 2008).

The publishing culture of the fields and expertise of the researchers are central issues to consider whenever the matter of international visibility is being discussed. Brazilian science is gaining space in international databases but it seems that some other requisites are need to gain international audience, including the establishment of a strong national policy towards better training of researchers and journals in English proficiency.

\section{FINAL REMARKS}

The process of institutionalization of the science and technology sector in Brazil has its origins in the 1950s. This process involved different spheres of the public sector, mainly, and was counted with numerous initiatives. It lasted at least three decades but was successful in the advancement and consolidation of a huge scientific and technological infra-structure in the country.

A natural consequence was the rising of several input and output indicators, such as the increase in the number of researchers, number of degrees, the number of enrollments and the number of publications in different media, mainly in specialized journals. The data presented here corroborates two previous studies on Brazilian science but calls attention to two aspects: the increase and qualification of personnel to $S \& T$ activities and the role of Brazilian journals.
No one doubts that the increase and qualification of personnel to science represents one of the main features for the enlargement and consolidation of science in Brazil. Nevertheless, the close relationship between graduate courses and scientific activities in Brazil introduces a strong distortion: to be a researcher in Brazil is roughly a synonym of to be a professor/advisor in a graduate course. Hence, Brazilian science is entirely in the hands of graduate programs so any factor that affects one will affect the other. Although they are components of the university structure, it seems that graduate programs are independent units, subordinated not only to the universities rules but mainly to rules established by national evaluation, conducted by the Ministry of Education. To maintain its certification, each graduate program takes part in the evaluation process, being a hostage of the evaluation criteria, which includes productivity goals. This has reinforced the differences among private institutions, universities and research institutes in terms of leadership in Brazilian science. At present, graduate courses are, indeed, the country's main producers of scientific knowledge.

Finally, data presented here shows that a large fraction of Brazilian publications is found in journals edited in the country which have mostly been indexed recently in the two databases. This aspect seems to better explain the recent growth of Brazilian publications in Scopus and WoS than the increase in the total number of titles indexed in both databases. It seems obvious that one should expect that the number of publications per country increases once there are more titles indexed. Nevertheless, in the case of Brazil, the observed increase in not only in terms of the number of publications but also in terms of the share in the whole databases. Thus, such an increase seems to be a consequence of the indexing of new Brazilian titles in both WoS and Scopus. National journal, which assumed a supporting role in the dissemination of Brazilian science, has now become one of the major players.

\section{REFERENCES}

ABC. Science in Brazil. Rio de Janeiro: Academia Brasileira de Ciências, 2002.

BBC/Brasil. (2010). Produção científica do Brasil ultrapassa a da Rússia, indica levantamento. Available at:http://www.bbc.co.uk/ portuguese/ciencia/2010/01/100127_brasil_russia_ciencia_ rw.shtml

Brasil. Ministério da Ciência e Tecnologia. Ciência, Tecnologia e Inovação. Desafio para a sociedade brasileira - Livro Verde. Silva CG and de Melo LCP. (Coord.) Brasília: Ministério da Ciência e Tecnologia/Academia Brasileira de Ciências, 2001.

Brasil. Ministério da Ciência e Tecnologia. Livro Branco: Ciência, Tecnologia e Inovação. Brasília: Ministério da Ciência e Tecnologia, 2002. 
Brito Cruz CH. (2007). Ciência e tecnologia no Brasil. Revista USP (73) $58-90$.

Chaimovich H. (2000). Brasil, ciência, tecnologia: Alguns dilemas e desafios. Revista Estudos Avançados 14(40) 134-43.

de Meis L, Arruda AP, Guimarães J. (2007). The Impact of Science in Brazil. IUBMB Life, 59(4-5) 227-34.

FAPESP. Indicadores de Ciência, Tecnologia e Inovação em São Paulo 2001. Francisco Romeu Landi (Coord). São Paulo: FAPESP, 2002.

FAPESP. Indicadores de Ciência, Tecnologia e Inovação em São Paulo 2004. Francisco Romeu Landi (Coord). São Paulo: FAPESP, 2005.

Folha de São Paulo. (2009). Produção científica cresce $56 \%$ no Brasil. Available at:http://www1.folha.uol.com.br/folha/ciencia/ ult306u561181.shtml

Glänzel W, Thijs B, Leta J. (2006). Science in Brazil. Part 1: A macrolevel comparative study. Scientometrics, 67(1) 67-86.

Ingwersen P. Brazil research in selected scientific areas: Trends 1981-2005. In: Proceedings of ISSI 2009 - the 12th International Conference of the International Society for Scientometrics and Informetrics: Rio de Janeiro, Brazil, 2009. LARSEN, B. \& LETA, J. (eds.). v. 2, p. 692-6.

King C. (2009). Brazilian Science on the Rise. ScienceWatch. Available at:http://sciencewatch.com/ana/fea/09julaugFea/

Leite P, Mugnaini R, Leta J. (2011). A new indicator for international visibility: exploring Brazilian scientific community. Scientometrics, v. 88, p. 311-19.

Leta J. Growth of Brazilian Science: a real internalization or a matter of databases' coverage? In: Proceedings of ISSI 2011 - the $13^{\text {th }}$ International Conference of the International Society for Scientometrics and Informetrics: Durban, Africa do Sul, 2011, v. 1, p. 392-7.

Leta J, de Meis, L. (1996). A profile of science in Brazil. Scientometrics, 35(1) 33-44;

Leta J, Glanzel W, Thijs B. (2006). Science in Brazil. Part 2: Sectoral and institutional research profiles, Scientometrics, 67(1) 87-105.

MCT Ministério de Ciência e Tecnologia, 2010c. Diretório de Grupos de Pesquisa. Série históricas. Available at: http://dgp.cnpq.br/ censos/series_historicas/index_pesquisadores.htm

MCT. Ministério de Ciência e Tecnologia, 2010a. Indicadores sobre o ensino de pós-graduação. Brasil: Alunos novos, matriculados ao final do ano e titulados nos cursos de mestrado e doutorado, 1987-2010. Available at:http://www.mct.gov.br/index.php/content/ view/6629.html
MCT. Ministério de Ciência e Tecnologia, 2010b. Indicadores sobre pesquisadores e pessoal de apoio, Brasil: Pesquisadores, em número de pessoas, por setor institucional e nível de escolaridade, 2000-2010. Available at: http://www.mct.gov.br/ index.php/content/view/5860.html

Meadows AJ. Communication in Science. London: Butterworths, 1974.

Meneghini R. (1996). The key role of collaborative work In the growth of Brazilian science in the last ten years. Scientometrics, 35(3) 367-73.

Morel RLM and Morei CM. (1977). Um estudo sobre a produção científica brasileira, segundo os dados do Institute for Scientific Information (ISI). Ciência da Informação 6, 99-109.

Pereira NP. (2007). Fundos setoriais no Brasil: um pouco da história. Ciência e Cultura, 59 (04) http://cienciaecultura.bvs.br/pdf/cic/ v59n4/a16v59n4.pdf

Pinheiro-Machado R, Oliveira PL. (2001). The Brazilian investment in science and technology. Brazilian Journal of Medical and Biological Research, 34, 1521-30.

Regalado A. (2010). Brazilian Science: Riding a Gusher. Science, $330,1306-12$.

Reist-2. The European Report on Science and Technology Indicators 1997. EUR 17639. Brussels: European Commission, 1997.

Schwartzman S. A space for science: the development of the scientific community in Brazil. University Park: Pennsylvania State University Press, 1991.

Scopus, What does it cover? Content Coverage Guide. 2012 Available at: http://www.info.sciverse.com/scopus/scopus-in-detail/facts

Sikka P. (1997). Statistical profile of science and technology in India and Brazil. Scientometrics, 39(2) 185-95.

UNESCO Science Report 2010. The Current Status of Science around the World. Paris: UNESCO, 2010.

Vasconcelos SMR, Sorenson MM, Leta J. (2009). A New Input Indicator for the Assessment of Science \& Technology Research? Scientometrics, v. 1, p. 217-30.

Zanotto ED. (2002). Scientific and technological development in Brazil. The widening gap. Scientometrics, 55(3) 383-91.

WoS, Web of Science, a Web of Knowledge database, 2012. Available at: http://wokinfo.com/products_tools/multidisciplinary/ webofscience/ 